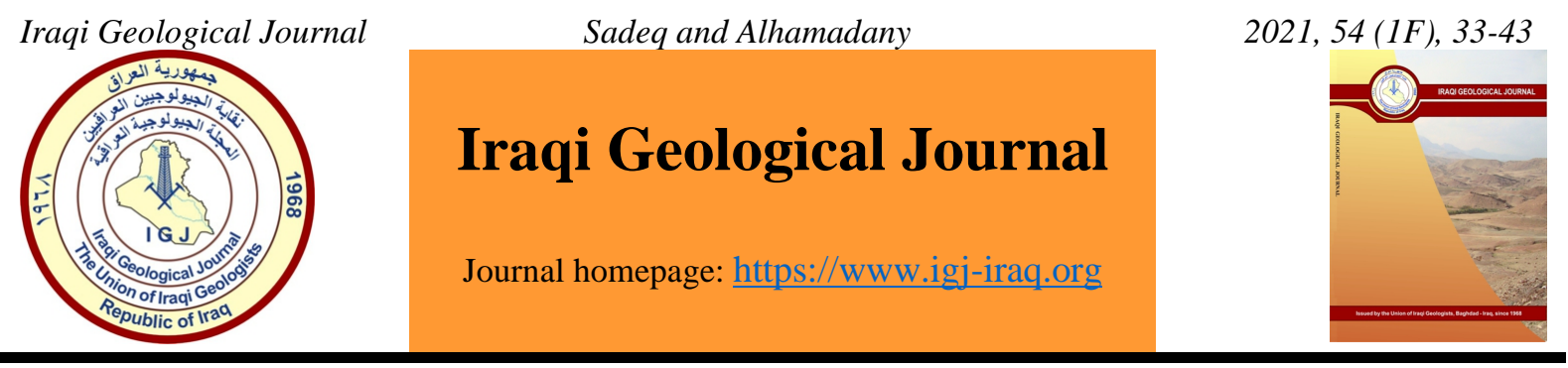

\title{
Geometric Study of the Lesser Zab River Channel Between Altun-Kupri City and Dibbs Dam, Kirkuk, Northern Iraq
}

\author{
Soran N. Sadeq ${ }^{1}$ and Tareq H. Alhamdany ${ }^{1}$ * \\ ${ }^{1}$ Department of Applied Geology, College of Science, University of Kirkuk, Kirkuk, Iraq \\ *Correspondence: tariqhassan685@ gmail.com
}

Received: 19 February 2021; Accepted: 19 April 2021; Published: 30 June 2021

\begin{abstract}
River Lesser Zab in N Iraq flow regime has been changed as a result of building a number of dams across the river course causing the cross-section of the river to vary in time and space. The aim of this study is to investigate the morphological changes for the river channel from AltunKupri City to Dibbs Dam. Five cross-sections were studied to explain the relation between hydraulic geometry parameters (width, depth, and velocity) versus river discharge using linear regression analysis, and the results show that river discharge does have a direct linear relationship with the morphologic parameters of the river channel, and the width-depth ratio has a positive linear relationship with mean flow velocity, and negative nonlinear relationships with cross-section area, indicating widening of river reaches due to the morphological and geologic components of river banks. The meander channel system in the study area can be described as a single phase, irregular width variation with high lateral erosion rate for a meander bend. Also, the river has numerous perennials elongated to subrounded alluvial islands, which are covered by shrubs or houses for local inhabitants. These outcomes are expected to be useful in developing water resources projects in the area.
\end{abstract}

Keywords: Hydraulic geometry; River; Meandering; Lesser Zab; Altun Kupri

\section{Introduction}

Rivers are considered as the lifelines of human civilization because they have always been essential for various human purposes; (water for domestic, livelihoods, industrial and agricultural purposes). Over time, rivers respond to changes in the environment through the processes of erosion and sedimentation, or by the direct influence of the human role changing river hydraulic geometry through engineering works such as dam construction. Various studies, conducted to predict the morphology of the river and to correlate hydraulic channel geometry variables. Leopold and Maddock (1953) studied hydraulic geometry analysis of river channels to calculate the relationship between hydraulic variables such as the width of the river channel, average depth, and mean velocity with river discharge changes. They are mathematically interrelated as a power function using the linear regression model. Rosgen (1994 and 1996) classified the stream system according to several hydrological, geological and hydraulic geometry features of the river basin (Hadadin, 2017). Schumm (1968) evaluates several empirical data taken from sandy bed channels to study the influence of boundary sediments on meander wavelength using an index based on the percent of silt and clay content in the river bed and bank

DOI: $10.46717 /$ igj.54.1F.4ms-2021-06-24 
deposits. He finds out that the meander wavelength decreases by increasing fine sediments in the stream bed or banks. Brice (1964) differentiated analytically between stable and eroded bank streams based on the rate of width change along the river course. Modern hydrological studies are based on field measurements to construct models such as numerical, physical, and environmental models (Hu and Bian, 2009). These models need a large number of data to have the best model simulation (Kumar et al. 2010). So the most precise model must be chosen (Farzan et al., 2019). Lesser Zab is a trans-boundary river that originates in Iran and joins the Tigris River in Iraq just near Alzwiah village (south of Mosul city), its approximately 400 kilometers long, drains an area of about 22,000 square kilometers. The larger part of the basin (74\%) is within Iraqi borders (Frenken, 2009). The changes that occur on this river are inside the Iraq border, where two dams (Dukan Dam and Dibbs Dam) have been built on the river channel, regulating the river flow. Accordingly, this paper evaluates and analysis the measurements of a series of field survey used to figure out the channel processes and dynamic for a part of lesser Zab river system running through several cities and villages located between Altun-kupri city and Dibbs dam. Hydraulic geometry parameters considered in this study include river velocity, depth, and width measurement as a function to channel flow only in a downstream direction. The alluvial islands in the river are studied to identify the processes that cause the formation of them in the river course. Furthermore, this study is to emphasize the analysis of the different meander parameters of the river. Finally, this study attempted to find an objective method to forecast the morphological and hydraulic relations at any given cross-section on a river channel.

\section{Material and Methods}

\subsection{Study Area}

The studied area is a part of Lesser Zab River (LZR), located between Altun - Kupri city and the Dibbs Dam of about $12 \mathrm{~km}$ length, within coordinates $36^{\circ} 46^{\prime}-35^{\circ} 43^{\prime} \mathrm{N}$ and $44^{\circ} 08^{\prime}-44^{\circ} 18^{\prime} \mathrm{E}$ (Fig. 1). The average temperature of the river basin at the studied area is $4.9{ }^{\circ} \mathrm{C}$ in January to $43.9{ }^{\circ} \mathrm{C}$ in July). Meanwhile the average annual precipitation is $334.32 \mathrm{~mm}$, the values of the rainfall of winter and spring are the most effective for the creation of river discharge, as the surface runoff is about $\% 30.4$ of the rainfall (Jirjees et al., 2020).

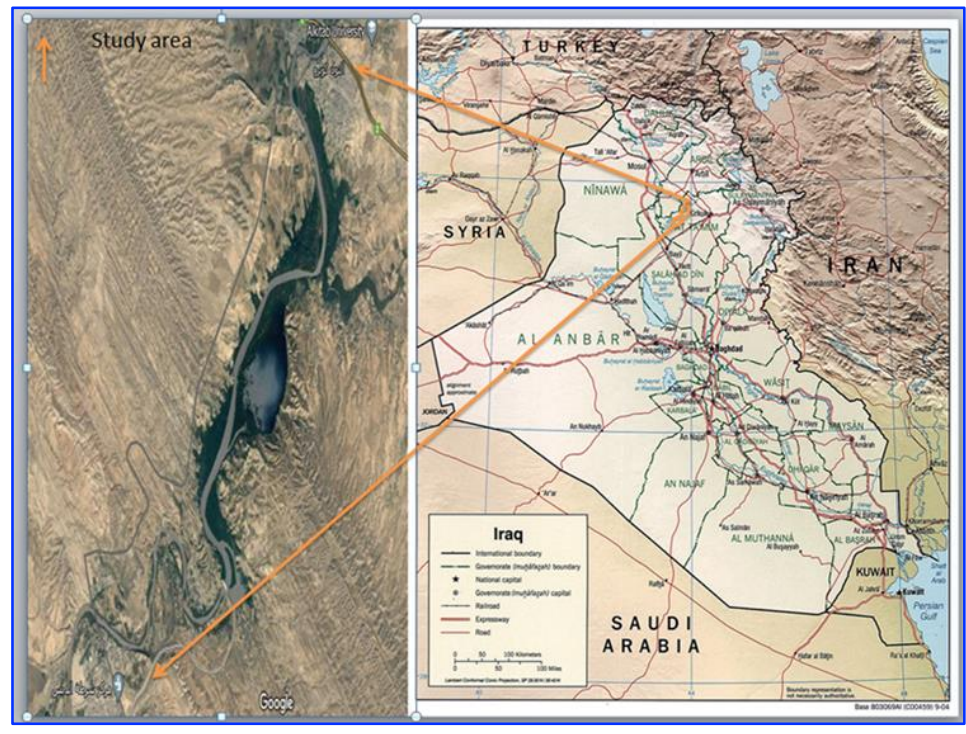

Fig.1. Location map of the studied area

The river passes through different geological formations belongs to the Tertiary age (Jassim and Buday, 2006). The main exposed formations in the area are Injana, Mukdadiya, Bai Hassan formations which 
includes the main underground water aquifer in the middle section of the LZR basin (Awadh et al., 2015, Al-Hamdani et al., 2016), some of them appears as ridges at the right bank of the river (Fig. 2).

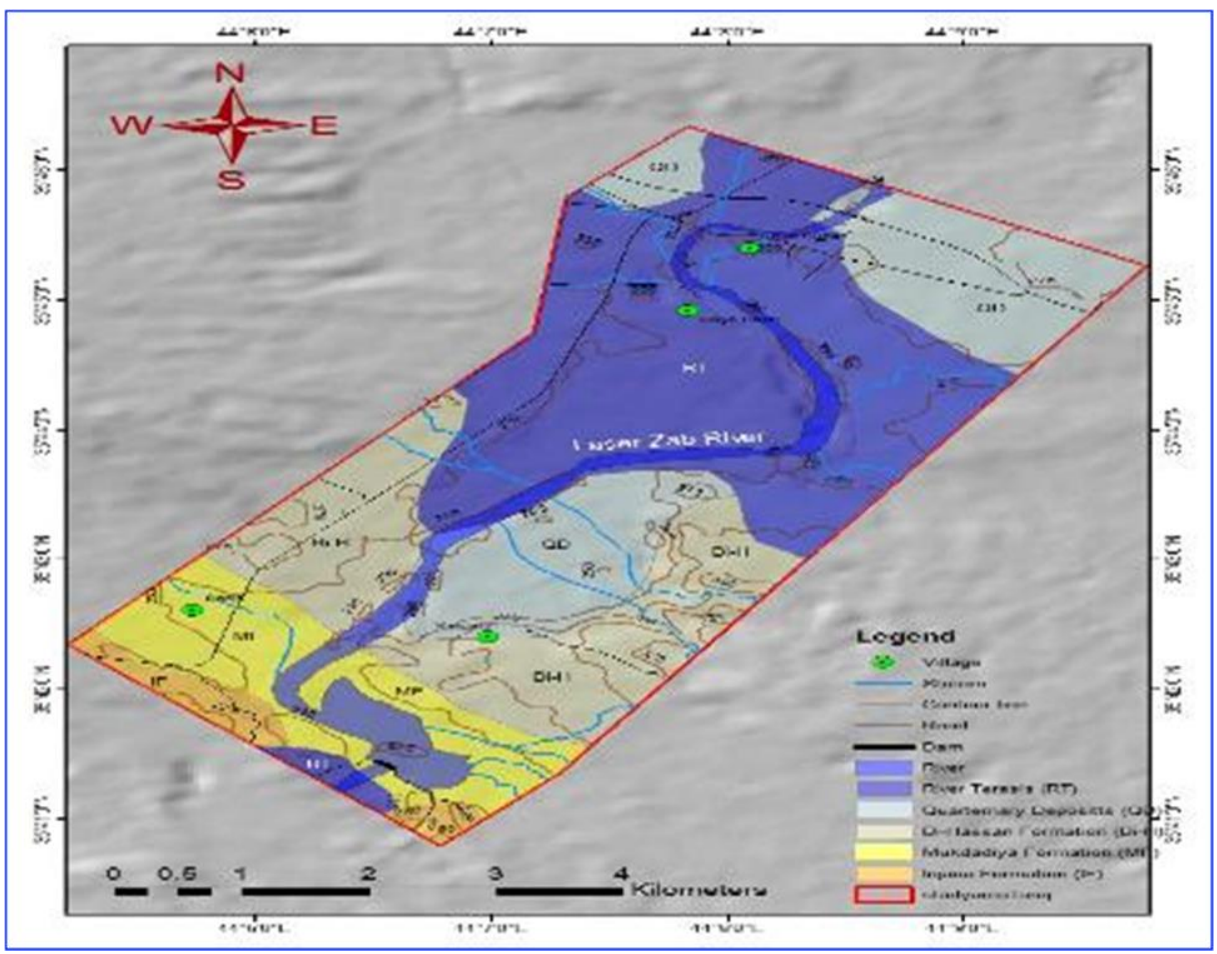

Fig. 2. Geological map of the studied area

\subsection{Data Preparation}

Based on measurements of field survey (bathymetric survey) data using Echo sounder Type (HONDEX HE-51C, V.2), five cross-sections were selected to measure the hydraulic geometry of the river channel (width, depth, valley side slope), where the measurement was within straight and meandering parts of the river course (Fig.3). River velocity was measured at each location using a current meter (V Tech water velocity indicator) (Table. 1).

Table 1. LZR channel parameters

\begin{tabular}{ccccccc}
\hline Location & $\begin{array}{c}\text { Width } \\
\text { W(m.) }\end{array}$ & $\begin{array}{c}\text { Mean depth } \\
\mathbf{D}(\mathbf{m} .)\end{array}$ & $\begin{array}{c}\text { Max. Depth } \\
(\mathbf{m} .)\end{array}$ & $\begin{array}{c}\text { Velocity } \\
\mathbf{V}(\mathbf{m . s}-\mathbf{1})\end{array}$ & $\begin{array}{c}\text { DischargeD } \\
(\mathbf{m 3 . s}-\mathbf{1})\end{array}$ & $\begin{array}{c}\text { Width / mean } \\
\text { depth ratio (F) }\end{array}$ \\
\hline A-A $^{-}$ & 56 & 2.19 & 3.12 & 0.73 & 89.523 & 25.57 \\
B-B $^{-}$ & 62 & 1.84 & 2.7 & 0.96 & 109.517 & 33.69 \\
C-C $^{-}$ & 65 & 3.21 & 4.3 & 0.87 & 181.523 & 20.25 \\
D-D $^{-}$ & 73 & 3.7 & 6.5 & 0.85 & 229.585 & 19.73 \\
E-E- & 77 & 4.28 & 7.2 & 0.83 & 273.535 & 17.99 \\
\hline
\end{tabular}




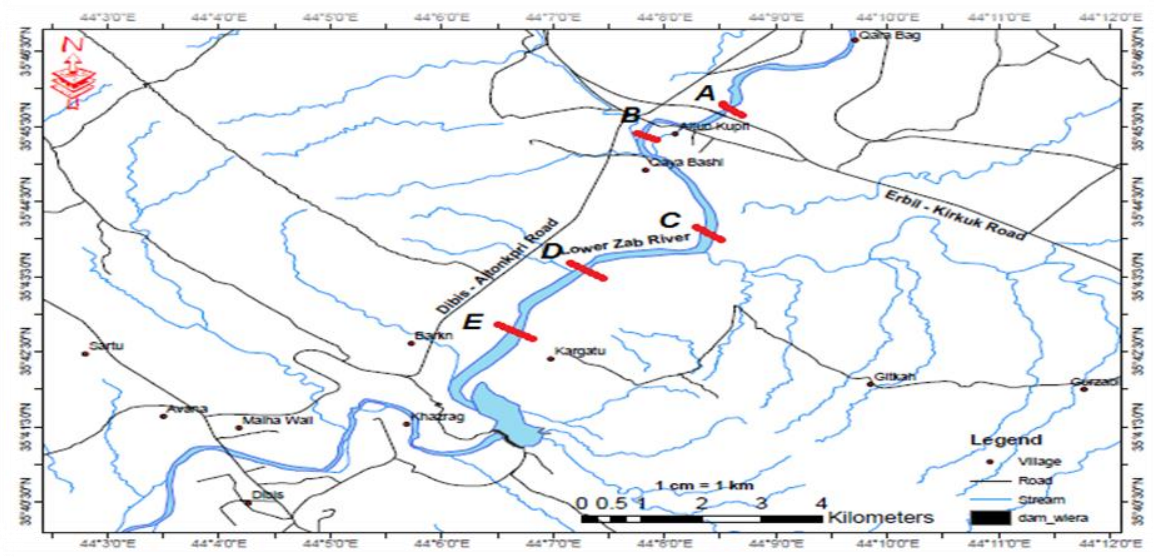

Fig. 3. River cross section sites
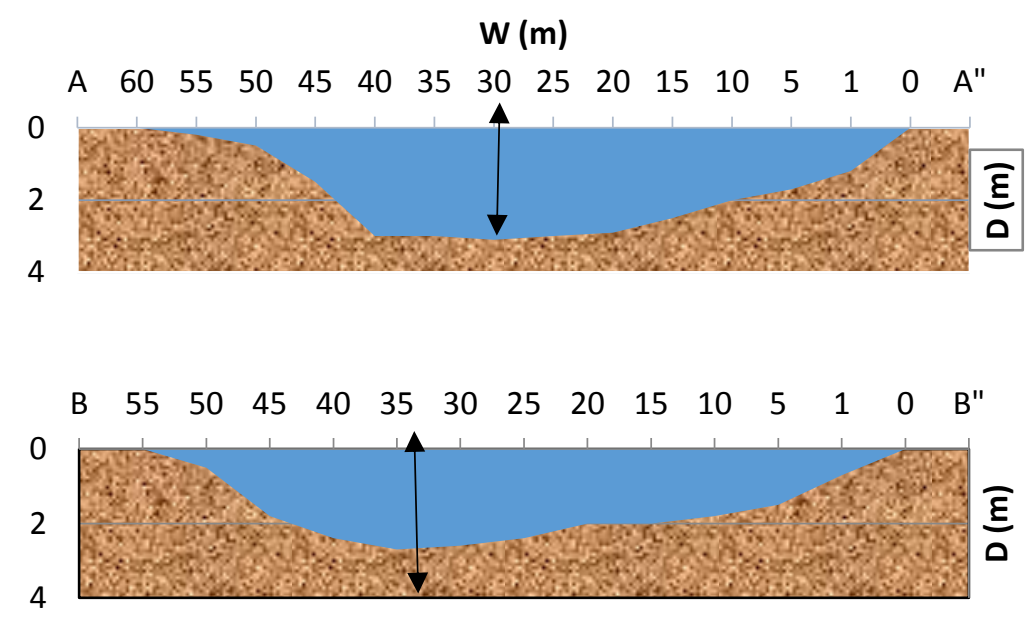

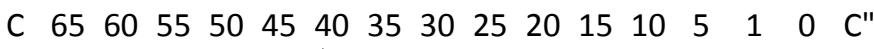

0

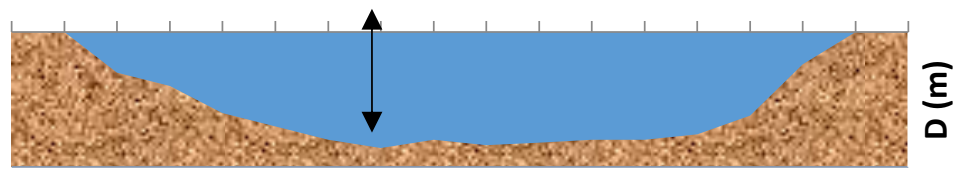

D" $75 \begin{array}{lllllllllllllllll}70 & 65 & 60 & 55 & 50 & 45 & 40 & 35 & 30 & 25 & 20 & 15 & 10 & 5 & 1 & 0 & \text { D" }\end{array}$

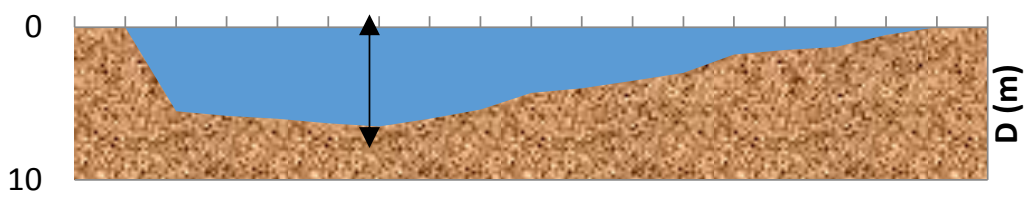

E $7570 \quad 656055504540 \quad 35 \quad 3025 \quad 2015 \quad 10 \quad 5 \quad 1 \quad 0 \quad E^{\prime \prime}$

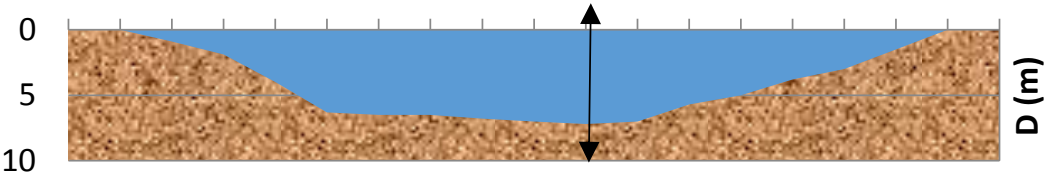

Fig.4. Typical channel cross-sections of the river in the study area 
The definitions of hydraulic channel geometry and meandering of the LZR follows Leopold and Maddock (1953). The measured hydraulic geometry parameters of a river channel at a given crosssection are related to discharge through power function mathematical expressions. The expressions derived to any given cross-section vary only in numerical constants of coefficients and exponents, as follows:

$$
\begin{gathered}
w=a \mathrm{Q}^{b} \\
d=c \mathrm{Q}^{\mathrm{f}} \\
v=k \mathrm{Q}^{\mathrm{m}}
\end{gathered}
$$

Where $\mathrm{w}$ is the width of the channel, $\mathrm{d}$ is the mean depth, and $\mathrm{v}$ is the flow velocity, $\mathrm{Q}$ is flow discharge of the cross-section, while $\mathrm{a}, \mathrm{c}$ and $\mathrm{k}$ are numerical constants, and $\mathrm{b}, \mathrm{f}, \mathrm{m}$ are exponents of the relation (Sing et al., 2003). The product of multiplication of coefficients a, c, k must equal one (Copeland et al., 2005), as the sum of the exponent's equals1.0, which satisfies the requirements of the continuity principle (Augustus et al., 2014).

The characteristics of the meandering channel geometry of the LZR following Leopold, Wolman, and Miller (1964) and Leopold and Wolman (1957) are as follows. Meander length (L) is the linear distance between two successive points of the meander belt. Amplitude (A) is the linear distance between the crest and the corresponding trough with reference to the channel centerline. The radius of curvature (Rc); is the regular sinusoidal bend made by rivers. Arc distance (Ad) is the length measured along the channel centerline from one point of inflection to the next (Purkait\& Sinha, 2019). Sinuosity $(\mathrm{K})$; is the ratio of the length of the channel midline to the total length of the stream measured along the center of the meander curve (Mohamed el al., 2017). Arc GIS (Version10.4) software, based on a digital elevation database of ( $30 \times 30 \mathrm{~m}$ EDM), downloaded from USGSEE, and used to draw various maps to describe the river characteristics (River basin, islands, meandering).

\section{Results and Discussion}

\subsection{Channel Hydraulic Geometry}

The followings are the mathematical relations between the morphological parameters and discharge for the LZR:

$\mathrm{W}=17.779 \mathrm{Q} 0.2583$

$\mathrm{D}=0.0799 \mathrm{Q} 0.7058$

$\mathrm{V}=0.7037 \mathrm{Q} 0.0359$

The values of $\mathrm{b}+\mathrm{f}+\mathrm{m}=0.2583+0.7058+0.0359=1.0$

Hence, the coefficients $\left(a_{x} c_{x} k=17.779_{x} 0.0799 \times 0.7037=1.0\right)$.

The results are satisfying the continuity principles, as well as the river discharge does have a direct, uniform, and linear relationship with the morphologic parameters of the river channel (Fig. 5). Meanwhile, the depth-discharge relation shows more rapid change than the other two variables in the downstream direction. The strength of the above relationships was examined using Pearson's correlation coefficient method represented by $r$ values. A value of $r=0.99$ is estimated for the $c$ width of the channel and discharge relationship with a coefficients of determination $r^{2}$ of $98 \%$; for channel depth-discharge relation ( $r=0.95)$ with $r^{2}$ of $90.25 \%$, and $r=0.90$ with $\left(r^{2}\right.$ of $\left.81 \%\right)$ for the relation between velocity of the river and its discharge. The results were all found to be significant at a 0.01 confidence level. 

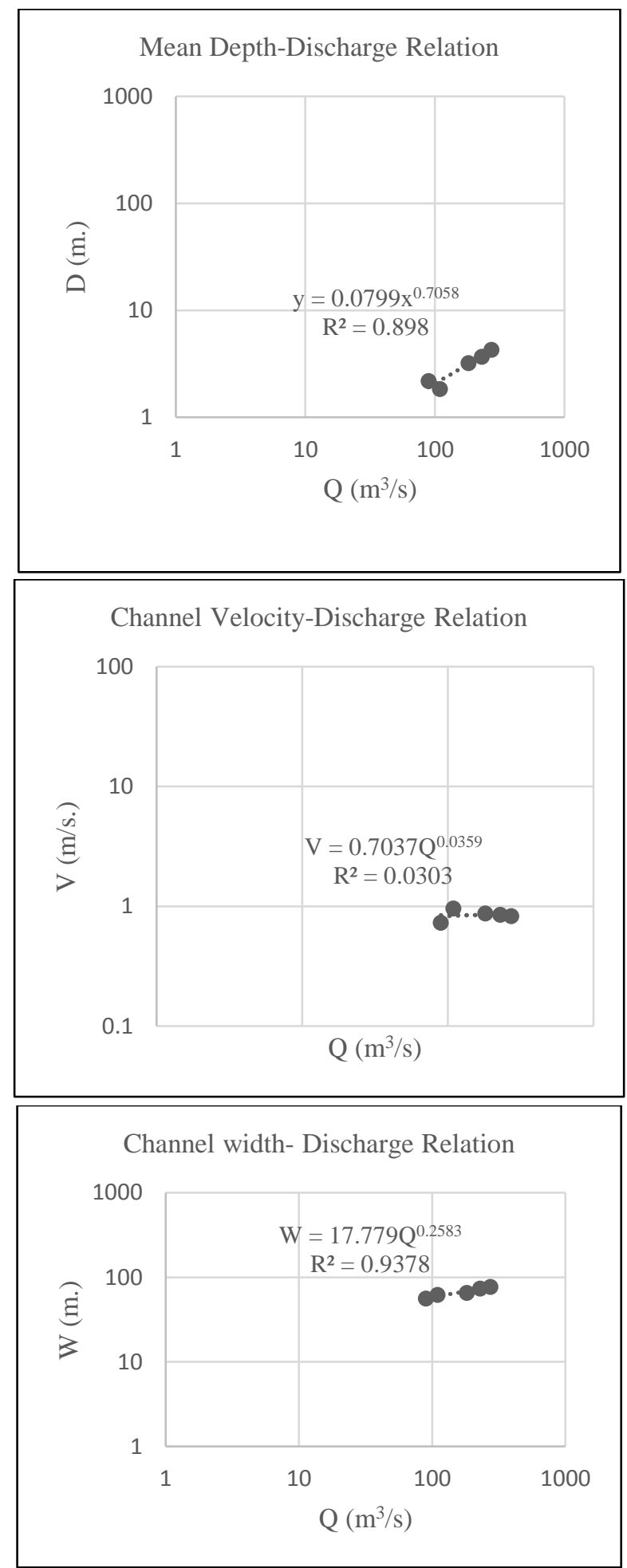

Fig.5. Channel width W-discharge Q, channel depth D-discharge Q and channel velocity V-discharge $\mathrm{Q}$ relationships of the LZR

\subsection{The Width-Depth or form Ratio (F)}

The ratio width-depth (W/D) is a measure of river channel shape related to boundary resistance and sediment transport (Schumm, 1968). The calculated F value for the studied area is 23.44 according 
to Rosgen (1996), ranging between $>12-<40$ showing that the river channel in the study area has the following characteristics: gentle slope, sinuous, having point bar at the river meander, the bed features slightly consistent riffle/pool reaches, with wide alluvial channels, and distinctive floodplains (EPA,2018). Hydrological Field measurements data shows a positive linear relationship between the ratio (W/D) versus mean velocity of the flow as (W/D >1), while a negative nonlinear relationship was governing the ratio (W/D) relation with the cross-section area indicating a widening of river reaches (Fig.6), reflecting the morphological and geologic components of river banks ( Zhang et al, 2009). These may reflect the actual hydrological properties of the middle LZ river channels.

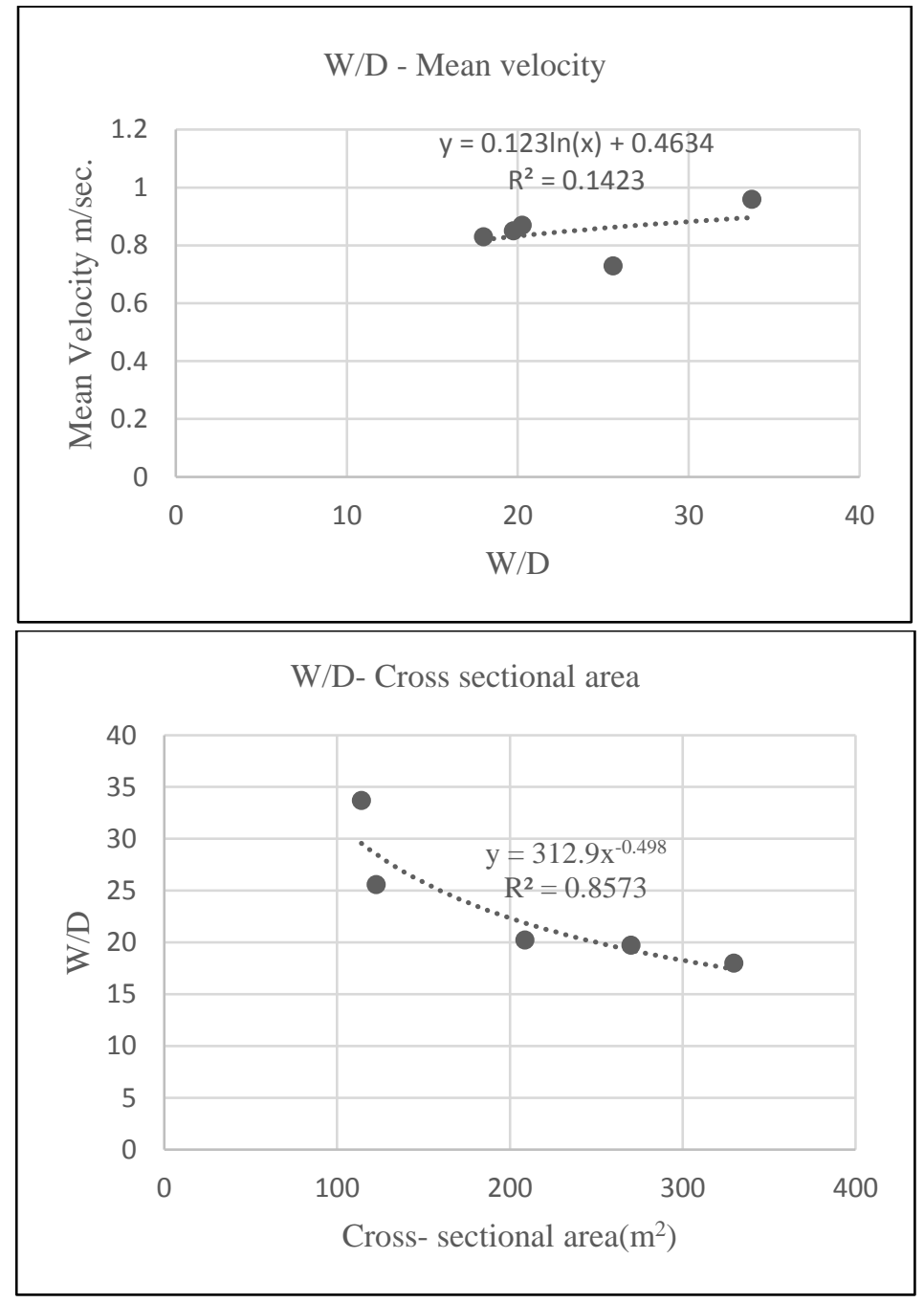

Fig.6. LZR (Width-Depth) - mean velocity and cross-sectional area relationship

\subsection{Channel Alluvial Islands}

The LZR in the studied area is almost stable, moderately sinuous with several branching reaches, including about 7 large perennial elongated to subrounded alluvial islands (Fig.7) with an average surface area of $0.2 \mathrm{Km}^{2}$ for each (Table3), mostly located at the middle and the right bank of the river. These alluvial islands are covered by shrubs or houses for local inhabitants. Island location, shape, and geomorphic expression suggest islands originate due to many causes such as low river bed slope, river meandering, high amount of river sediments load (about 2.8*103 ton/year) (Alnaqash\&Alsahaf, 1987) during heavy rainfall season causing the high level of river high discharge, contributing high quantities of sediment to the river. Meanwhile human activity plays an important role to build such islands. 
Table 3. River alluvial island in the studied area

\begin{tabular}{llc}
\hline LZR island No. & Shape & Area $\left(\mathbf{m}^{\mathbf{3}}\right)$ \\
\hline 1 & Polygon & 45.5008 \\
2 & Polygon & 2955.53 \\
3 & Polygon & 377.666 \\
4 & Polygon & 11485 \\
5 & Polygon & 2058.05 \\
6 & Polygon & 3901.89 \\
7 & Polygon & 80560.9 \\
\hline
\end{tabular}

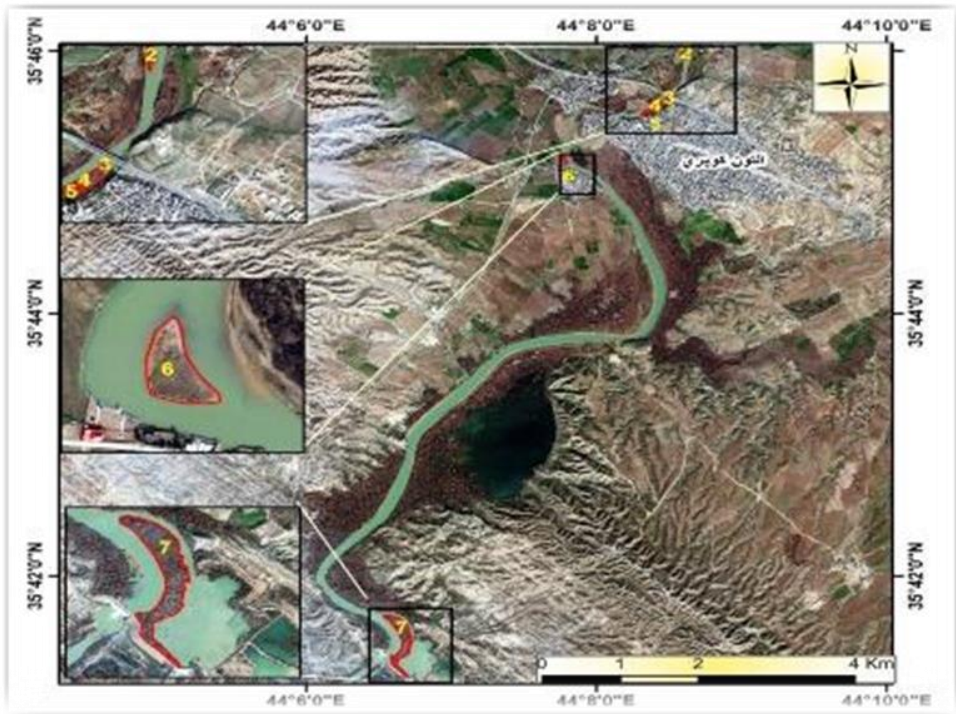

Fig.7. Channel alluvial islands in the studied area

\subsection{Meandering Channel}

The followings are the measured parameters for the widest channel of the multi-channel river at the studied area (Fig. 8):

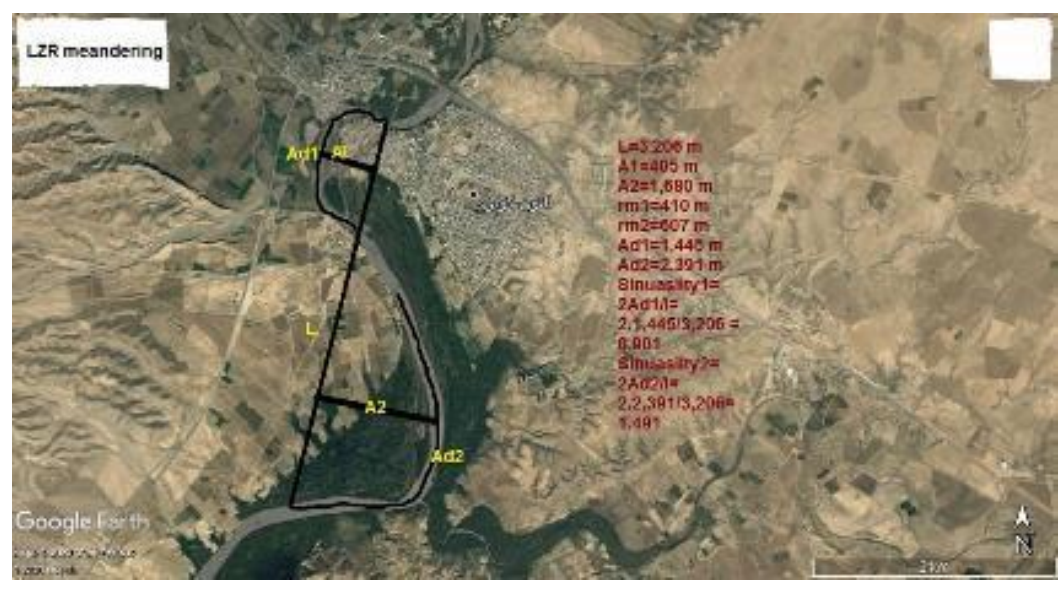

Fig.8. LZR meandering channel geometry 
Where:

Bank full channel width at crossover $=291 \mathrm{~m}$

Actual width (at the time of measurement) $=73 \mathrm{~m}$

Radius of curvature $=607 \mathrm{~m}$

Arc distance $=2391 \mathrm{~m}$

Meander wave length $=3206 \mathrm{~m}$

Amplitude $=1680 \mathrm{~m}$

Total length of multi-channel meander $=5219 \mathrm{~m}$. Then the Sinuosity $=1.49$

The meander channel in the study area may be classified according to Jackson (1978) as sandy rivers with polygonal point bars. In meandering reaches, the point bar shows a steady deposition of thin layer of fine sediments especially at places where slopes are steep, while the medium -coarse sand, forms the upward fining layers, and this is may be due to fluctuation in upstream sedimentary supply recorded for meandering rivers (Slowik et al., 2017). According to Rhoads and Welford (1991); the Meandering channel system are favored by conditions of a high degree of sinuosity about (1.49) characterized by single phase, irregular width variation. River banks slopes are low (42 $2^{\circ}$ (Fig. 9), and width/depth (F) ratios of less than 40. The relationship between meander wavelength is about (11) times the channel width as reported by Leopold and Wolman (1957 and 1960). Thus, the LZR river meander at the studied area is of a single channel type with a well-developed bend, maximum bend sharpness.

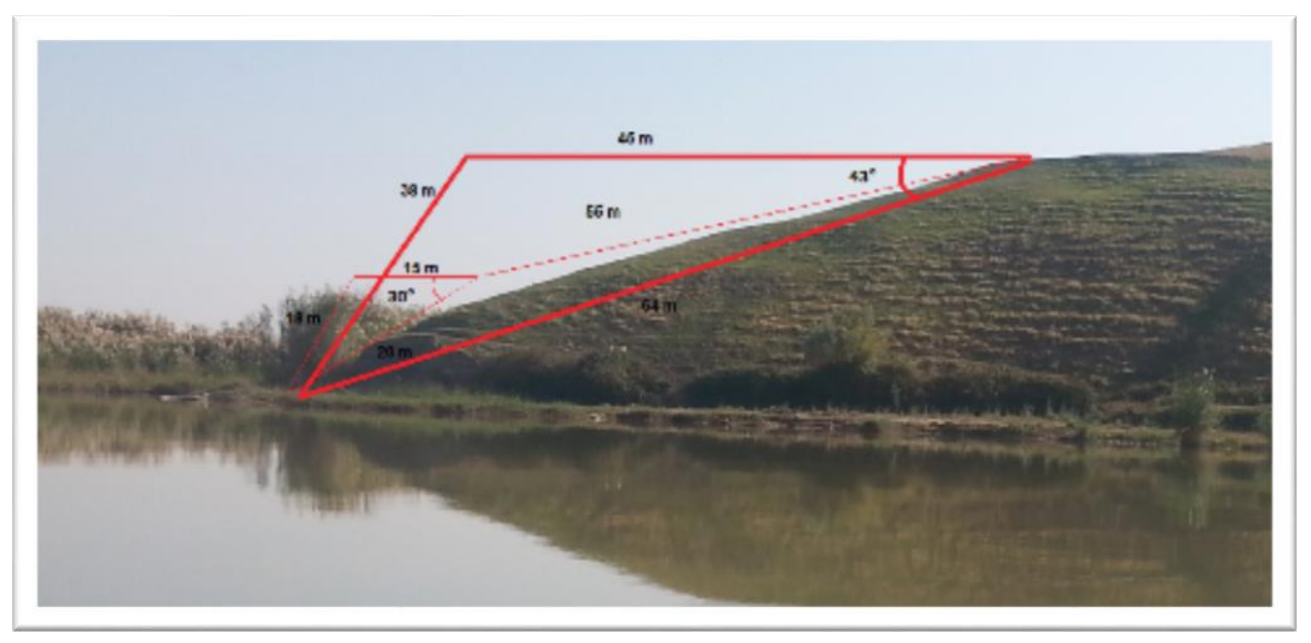

Fig.9. River bank slops at the widest channel of the river meander

Also, through meandering, a specific case of "lateral-accretion deposit" is produced, having a distinctive sedimentary structure (Allen,1982), and the maximum rate of such erosion will occur at the point bar as the radius of curvature is about (2.08) times the width at the crossing.

\section{Conclusions}

Appropriate knowledge and results of river channel hydromorphological parameters and relationships studies are useful in developing and designing water resources. This study shows that the river discharge does have a direct, nonlinear relationship with the morphologic parameters of the river channel. The sum of exponents and coefficients for river hydraulic geometry parameters relationships at each cross-section equal to one. Furthermore, the depth-discharge relationship tends to have more rapid change than the velocity and width via discharge relationship in the downstream direction because of the reduction of the flow velocity in that direction due to the changing sediment and boundary 
conditions. River alluvial islands emerged as one of the geomorphological features that characterize the LZR. The number of islands in the study area reached seven islands, mostly are elongated to subrounded shape with an average surface area of $0.2 \mathrm{Km} 2$ for each almost located at the middle and the right bank of the river. Island location, shape, and geomorphic expression suggest that these islands are unstable, some may disappear, and some will change their dimensions, and the change is in the direction of the movement of water currents. These islands are covered by shrubs or houses for local inhabitants. characterized by woody vegetation or human habitation, they are originated due to many causes; primarily attributed to the river regime, high amount of river sediments load during heavy rainfall season, and human activity throughout the building of several dams across the river course which has a great effect in reserving large quantities of sediments in dam lakes affecting the development of river island. This paper offers an opportunity to study the meandering channel system in the study area, which is favored by conditions of a high degree of sinuosity (1.49) characterized by single-phase, irregular width variation. The meander wavelength is generally about 11 times the width, having a welldeveloped bend, maximum bend sharpness, maximal rate of lateral erosion will occur at the point bar as the radius of curvature is about two times the width at the crossing. The above results can further be improved through additional hydrological measurements and studies to assist in the spatiotemporal variability of the hydrological parameters at any part of the LZR to be used in the development of water resources projects in the area.

\section{Acknowledgements}

The authors are very grateful to the Editor in chief Prof. Dr. Salih M. Awadh, the Secretary of Journal Mr. Samir R. Hijab. and the Technical Editors for their great efforts and valuable comments.

\section{References}

Al-Hamdani, J. A. J., Awadh, S. M., Ibrahim, O. S., 2016. Geochemical partitioning of heavy metals in the urban soil, Kirkuk, Iraq. Iraqi Geological Journal, 1-24.

Al-Naqash, A. B., Al-Sahaf, M. M., 1987. Geomorphology, Ministry of Higher Education and Scientific Research, University of Baghdad, $546 \mathrm{pp}$.

Allen, J. R. L., 1982. Developments in Sedimentology, Sedimentary Structures Their Character and Physical Basins. Vol. II, Volume 30, Part B., Elsevier, Amsterdam, 663p.

Augustus, O.A., Ifeanyichukwu, C. E., 2014. Channel dynamics and hydraulic geometry of two tropical deltaic catchments in Southern Nigeria. Landform Analysis, 27, 3-13.

Awadh, S. M., Al-Kilabi, J. A., Khaleefah, N. H., 2015. Comparison the geochemical background, threshold and anomaly with pollution indices in the assessment of soil pollution: Al-Hawija, north of Iraq case study. International Journal Science Research, 4(7),2357-2363.

Brice, J. C., 1964. Channel patterns and terraces of the Loup Rivers in Nebraska. US Government Printing Office.

Rhoads, B.L. and Welford, M.R., 1991. Initiation of river meandering. Progress in Physical Geography, 15(2), 127-156.

Copeland, R., Soar, P. and Thorne, C., 2005. Channel-forming discharge and hydraulic geometry width predictors in meandering sand-bed rivers. In Impacts of Global Climate Change,1-12.

EPA., 2018. Fundamentals of Rosgen Stream classification System. Watershed Academy Web. USEPA.

Farzin, S., Ahmad A., Ali H., Hadi A., 2019. Flow pattern study in Beshar River and its two straight and meander reaches using CCHE2D model. Applied Water Science, 10, 19.

Frenken, K., 2009. Irrigation in the Middle East Region in figures. AQUASTAT Survey, Water Report, 34, Rome: FAO.

Hadadin, N., 2017. Variation in hydraulic geometry for stable versus incised streams in the Yazoo River basinUSA. International Journal of Sediment Research, 32 (1), 121-126.

$\mathrm{Hu}$, S. and Bian, L., 2009. Interoperability of functions in environmental models: a case study in hydrological modeling. International Journal of Geographical Information Science, 23(5), 657-681. 
Jackson, R.G., 1977. Preliminary evaluation of lithofacies models for meandering alluvial streams. In Miall A.D.(E.d.). Fluvial Sedimentology. Canadian Society of Petroleum Geologists Memoir, 5, 543-576.

Jassim, S. A, Buday, T., 2006. Latest Eocene-Recent Mega sequence AP11. Chapter 14 in Geology of Iraq, S.A. Jirjees, S., Seeyan, S., Fatah, K. K., 2020. Climatic Analysis for Pirmam Area, Kurdistan Region, Iraq, Iraqi Geological Journal, 53(1E): 75-92.

Kumar, M., Bhatt, G., Duffy, C. J., 2010. An object-oriented shared data model for GIS and distributed hydrologic models. International Journal of Geographical Information Science, 24(7), 1061-1079.

Leopold, L.B., Maddock, T., 1953. The hydraulic geometry of stream channels and some physiographic implications (Vol. 252). US Government Printing Office.

Leopold, L.B., Wolman, M. G., 1957. River channel patterns: braided, meandering, and straight. US Government Printing Office.

Leopold, L. B., Wolman, M. G., Miller, J. P., Wohl, E., 1964. Fluvial processes in geomorphology. Courier Dover Publications

Mohamed, A., Sherif, M., Mustafa, M., 2017. Evaluation of Alluvial Channels Meandering Phenomenon Case Study: Bahr Youssef, Annals of Valahia University of Targoviste. Geographical Series, 17(2), 206-219.

Purkait, B., Sinha, S., 2019. Meander geometry, hydraulics and sedimentary structures: a case study of the Usri River section, Jharkhand, India. Arabian Journal of Geosciences, 12(9), 1-16.

Rosgen, D. L., 1994. A classification of natural rivers. Catena, 22, Elsevier, 169-199.

Rosgen, D. L., Silvey, H. L., 1996. Applied River Morphology (Vol. 1481). Pagosa Springs, CO: Wildland Hydrology.

Schumm, S. A., 1968. River Adjustment to Altered Hydrologic Regimen, Murrumbidgee River and Paleochannels, Australia (Vol. 598). US Government Printing Office.

Sing, V., Yang, C.T., Dong, Z.Q., 2003. Downstream hydraulic geometry relations: Theoritical development. 39,12, 1337.

Slowick, M., Deszo, J., Marciniak, A., Kovacs J. 2017. The formation of alluvial islands in a river course transformed by channel straightening and dam closures. Conference Paper: 11th International Conference on Fluvial Sedimentology. At Calgary, Canada.

Zhang, Q., Shi, Y., Xiong, M., 2009. Geometric properties of river cross sections and associated hydrodynamic implications in Wuhan- Giujiang River reach, The Yangtze River. Journal of Geographical Sciences, 19, 58-66. 